Journal of Research in Technical Careers

May 2019, Vol. 3, No. 1.

(C) Author(s)

\title{
Developing STEM Identity of Nez Perce Students: Identifying Entry-Level Competencies for Forestry and Fire Management
}

\author{
Raymond A. Dixon, Karla Eitel, Yudi Zhu \\ University of Idaho
}

\begin{abstract}
The purpose of this study was to identify the competencies that are required for entry-level forestry and fire management technicians. The strategy is a part of a larger goal to develop the STEM identity of Nez Perce students through the integration of relevant competencies in middle and high school curriculums. The DACUM process was used. Through this groupware process, nine experts from the Nez Perce Natural Resources produced a competency profile consisting of 12 duties and 79 tasks, along with general knowledge and skills, attitudes, tools, and future trends. Findings indicate that the experts view relevant cultural competencies as central to the function of the job and not as mere enablers. This has implications for how content is integrated, taught, and assessed in schools.
\end{abstract}

Keywords: job analysis, DACUM, forestry and fire management, culturally responsive pedagogy

In recent years the Pacific Northwest has seen extensive forest fires that have destroyed many homes and taken the lives of people and animals (Northwest Interagency Coordination Center, 2018). While these recurring fires have been blamed on climate change, which has resulted in much warmer and drier conditions (Gavin, et al., 2016; Hessburg, Agee, \& Franklin, 2005), what is clear is strategic forestry and fire management techniques will be required in order to reduce and contain these destructive fires in the future. In addition, the school curriculum will have to prepare a new generation of students to enter careers in forestry and fire management, equipped with the skills to tackle and manage this destructive element of nature (Goergen, Harding, Owen, Rey, \& Scarlett, 2013). The USA has approximately 751 million acres of forest, about one third of the country's total land area (USDA, 2011). Forty-four percent of forests are owned by national, state, and local entities and the rest are owned by private landowners, including more than 22 million family owners. The U.S forest area has remain relatively stable over the past century despite an increase in population, in comparison to wide-scale deforestation in other countries. This achievement is due to effective forest management practices (Hamilton, 2013).

\footnotetext{
cc $(7) \ominus$ Creative Commons CC-BY-NC-ND: This article is distributed under the terms of the Creative Commons Attribution 4.0 License (http://creativecommons.org/licenses/by/4.0/) which allows others to download your works and share them with others as long as they credit you, but they can't change them in any way or use them commercially.
} 
The United Nations Food and Agriculture Organization (2018) refers to forest management as:

the process of planning and implementing practices for the stewardship and use of forests and other wooded land to meet specific environmental, economic, social and cultural objectives. It deals with the overall administrative, economic, legal, social, technical and scientific aspects related to natural and planted forests. It may involve varying degrees of deliberate human intervention, ranging from actions aimed at safeguarding and maintaining forest ecosystems and their functions, to those favoring specific socially or economically valuable species or groups of species for the improved production of forest goods and services.

Many of the products people use, such as wood, paper, and medicine, come from forests. Forests are home to many natural resources, support a variety of wildlife, and serve as popular recreational areas. In addition, forests absorb and store carbon dioxide from the atmosphere, which is important for slowing the rate of global warming. Forests must be properly managed to ensure forest resources continue to be available in the future (Hamilton, 2013; Ward \& Patterson, 2012).

The management of fire is an essential part of forestry management. Native Americans have used periodic burning for many centuries as a means to manage the forest long before Europeans settled in North America. Today, fire is used effectively in forests as a form of habitat management to assist with agriculture and food production, reduce insects or disease, and promote ease of travel. Forest fires that are started naturally are nature's way of actively managing the landscape; however, naturally started wildfires are no longer allowed to burn unchecked because of the danger to human life and property (Agee, 1993; Wallin, Swanson, Marks, Cissel, \& Kertis, 1996). The lack of proper forest management has resulted in many forests becoming overly dense with excess growth and debris, which, when combined with weather events such as high temperature and strong winds and human activities such as the careless use and disposal of burning material or even the deliberate setting of fires, has resulted in an increase in the number and severity of uncontrolled forest fires (Hessburg, Agee, \& Franklin, 2005; Stephens et al., 2018).

Forests in north central Idaho are a part of the Nez Perce Native Americans' heritage. Preparing Nez Perce students with competencies to pursue careers in forestry as scientists and technicians is very important to the Nez Perce Tribe and the various stakeholders associated with Nez Perce natural resources. To that end, the College of National Resources in partnership with the Nez Perce Tribe in north central Idaho received funding to conduct a project to develop the science, technology, engineering, and mathematics (STEM) identity of Nez Perce students. Through a series of structured curriculum engagements, students were exposed to the use of Unmanned Aerial Vehicle (UAV) and remote sensing technologies to understand scientific concepts and conduct scientific inquiries related to natural resources. A goal of this program was to identify the competencies of an entry-level forestry and fire management technician and determine which of these competencies can appropriately be integrated in the middle and high school curriculums. 


\section{Literature Review}

The forest was the traditional home of the Nimiipuu (the People). The Nimiipuu were later named Nez Perce Indians by the Lewis and Clark expedition, and according to famed Nez Perce leader Chief Joseph, the Nez Perce people are of one mind with the earth always seeking to protect and preserve their rich natural environment and vast homeland (Nez Perce Tribe Forestry \& Fire Management Division, 2013; USDA Forest Service, 2018).

The Nez Perce National Forest was created by Executive Order No. 854 signed by President Theodore Roosevelt effective July 1 1908. The forest was established from lands given up by the Bitter Root and Weiser National Forests. In 1934, part of Selway National Forest was added by Executive Order No. 6889 (Nez Perce Tribe Forestry \& Fire Management Division, 2013). Historically, the Nez Perce people populated the area now known as Idaho, northeastern Oregon, southeastern Washington and western Montana. Today, Nez Perce Reservation encompasses some 770,000 acres of land in north central Idaho. The name Nez Perce-Clearwater National Forests was chosen when the forests administratively combined in 2012 (Nez Perce Tribe Forestry \& Fire Management Division, 2013).

Maintaining a harmonious and respectful balance in the use and management of the forest is an important part of Nez Perce's culture and value system. Timber resource is recognized as being only one component of the total forest resources. For example, forest properties provide opportunities for tribal members to enjoy cultural and recreational activities. Therefore, the health and productivity of timber resource is ultimately dependent on maintaining the overall health of all forest resources (USDA Forest Service, 2018). The Nez Perce people employ economically, socially, and environmentally responsible forest management practices as stewards of over 57,000 acres of commercial forest land. Income generated from the forest helps the tribal government to provide essential services to the community.

Careers in Forestry. Forestry provides services in forest management, timber harvest, forest development, and forest inventory and planning (Nez Perce Tribe Forestry \& Fire Management Division, 2013). Forestry offers several career paths that can lead to students becoming scientists and technicians. These include conservation scientists, foresters, environmental scientists and specialists, soil and plant scientists, wildlife biologists, environmental science and protection technicians, and forest and conservation technicians (Hamilton, 2013; Zilberman, 2016). Table 1 provides a brief description of potential forest occupations.

Job Analysis. Job analysis is a systematic process in which individuals make judgments and collect data to document the requirements of a job and the work performed (Brannick \& Levine 2002; Clifford, 1994). It "provides a detailed description of particular job duties, responsibilities, necessary skills requirements, and the work environment of a given job” (Morganson, Major, \& Bauer, 2009, p. 252). Job analysis is often the first step in a series of actions to create job descriptions, redesign jobs to promote efficiency, and 
Table 1. Description of Forest Occupations

\begin{tabular}{|c|c|}
\hline Forest Occupation & Brief Description \\
\hline Conservation scientist & $\begin{array}{l}\text { Manage, improve, and protect natural resources. Conservation scientists } \\
\text { work with forest owners, managers, and government agencies to devise } \\
\text { ways to use and improve land, while safeguarding the environment and } \\
\text { controlling erosion. }\end{array}$ \\
\hline Foresters & $\begin{array}{l}\text { Some primary duties of foresters include drawing up plans to regenerate } \\
\text { forested lands, monitoring the progress of those lands, and supervising } \\
\text { tree harvests. Foresters also create plans and do inspections to protect } \\
\text { forests from disease, harmful insects, and damaging wildfires. }\end{array}$ \\
\hline Environmental scientists and specialists & $\begin{array}{l}\text { Identify problems and find solutions that minimize hazards to the health } \\
\text { of the environment. }\end{array}$ \\
\hline Soil and plant scientists & $\begin{array}{l}\text { Research soil, plants, and other forest products. Soil scientists examine } \\
\text { the composition of soil as it relates to plant or tree growth and investigate } \\
\text { effects of alternative soil treatment practices on tree productivity. }\end{array}$ \\
\hline Wildlife biologists & $\begin{array}{l}\text { Study the characteristics of animals, such as their interactions with other } \\
\text { species, reproduction, diseases, and movement patterns. Wildlife } \\
\text { biologists do a variety of scientific tests and experiments, such as } \\
\text { collecting blood samples from animals, to assess their levels of nutrition. }\end{array}$ \\
\hline Biological technicians & $\begin{array}{l}\text { Assist scientists with tests, experiments, and analyses related to } \\
\text { sustainable forestry. They may set up, maintain, and clean laboratory } \\
\text { instruments and equipment, such as microscopes, scales, and test tubes. } \\
\text { They gather and prepare plant, water, and soil samples for laboratory } \\
\text { analysis. }\end{array}$ \\
\hline $\begin{array}{l}\text { Environmental science and protection } \\
\text { technicians }\end{array}$ & $\begin{array}{l}\text { Typically are supervised by environmental scientists and specialists. In } \\
\text { sustainable forestry, these technicians often work on teams with scientists } \\
\text { and other technicians, to solve problems related to environmental } \\
\text { degradation and public health. }\end{array}$ \\
\hline Forest and conservation technicians & $\begin{array}{l}\text { Generally are supervised by foresters. They assist with a variety of tasks, } \\
\text { including gathering data on water and soil quality, assessing fire hazards, } \\
\text { selecting and marking trees to be cut, tracking wildlife, and monitoring } \\
\text { the activities of loggers and other forest users. }\end{array}$ \\
\hline
\end{tabular}

determine training needs (Morganson et al., 2009). According to Siddique (2004), most writers view it as the backbone or cornerstone of nearly all human resources (HR) activities (Schuler \& Jackson, 1996; Sherman, Bohlander \& Snell, 1998) because it provides a rich source of information about jobs and job holders, which HR personnel use to develop important documents such as job description, job specification, and performance standards. Job analysis can be cost effective, it improves communication, accommodate change, and contribute to improved human resource management. Among several organizational processes, job analysis can also facilitate selection and staffing, training and development, and performance management (Latham \& Fry, 1988; Wooten, 1993; Carless, 2007). 
Singh (2008) indicated that since the 1950s job analysis has grown considerably in scope and application, especially over the last few decades, becoming an influential management tool in business and industry (Ghorpade \& Atchison, 1980; Gatewood \& Field, 1994). He opined, however, that many important assumptions that underlie the fundamental uses of job analysis in management are becoming questionable in today's business environment. Job analysis focuses on the collection of work-related information for the job as it currently exists and/or has existed in the past. The procedures are related more to a one-person, one-job situation. Yet, as competition and technological innovation increase and products life cycle gets shorter, jobs are becoming less static and individuallybased, therefore the capturing of knowledge, skills, and attitudes (KSA) may be beyond the scope of present forms of job analysis.

According to Cucina, Martin, Vasilopoulos, and Thibodeuax (2013), there are two broad categories of job analysis methods: job-oriented and worker-oriented. Job-oriented methods focus on the job itself and the work or tasks performed by incumbents, whereas worker-oriented methods focus on collecting information regarding the competencies required to perform a job. Similar to the foregoing, Morgeson (2017) described the job analysis methods used over the years as work-oriented, worker-oriented, and hybrid. Workoriented methods seek to describe what a worker does and worker-oriented methods seek to identify the characteristics needed to successfully perform job tasks. Hybrid methods combine elements of work- and worker-oriented methods.

Techniques used to conduct job analysis include observations, surveys, worker diaries, questionnaires, critical incidents, and interviews both individual and focus group (Chang \& Kleiner, 2002; Shetterly \& Krishnamoorthy, 2008). Job analyses generated by workers who are viewed as subject matter experts by their employers tend to display high consistency in the type of information revealed (Goffin et al., 2011). The use of subject matter experts has also been advocated for the predicting of future jobs (Sanchez, 1994). In addition, using expert panels provides information quickly and relatively cheaply compared to large samples responding to task inventories or other structured questionnaires (Brannick \& Levine, 2002). According Morgeson and Campion (1997), potential issues to be considered when conducting job analysis are social and cognitive processes that have the potential to negatively influence the quality of the job analysis. These effects include bias estimates of task criticality and less reliable data. The effects will vary based on factors such as the method of job analysis, data collection techniques, data sources, and the purpose of the job analysis. For example, in a study that explored the effect of subject matter expert viewpoint on job analysis data in the law enforcement context, Truxillo and associates (2004) found that one category of subject matter experts, i.e., district attorneys who were end users of the work product of police reports, had somewhat different job analysis response than the police who actually produce these reports.

\section{The Framework}

Developing a Curriculum (DACUM), the first stage of the Systemic Curriculum and Instructional Development (SCID) process (Norton, 1997; Finch, \& Crunkilton, 1999; Cooper, Aherne, \& Pereira, 2012), can be described as a hybrid method that identifies the 
tasks that are required to perform a job. It also provides information about theoretical knowledge, practical skills, and personal attitudes or dispositions needed to equip a person to perform at a particular level. The process was first conceptualized in the United States and Canada as a joint effort of the Canadian Department of Manpower and Immigration's Experimental Project Branch and the General Learning Corporation of New York as a means of designing and developing curricula that would be relevant to work place training (Zanella, 1999).

The DACUM process has been used extensively in industry, military, government, and a wide range of professions to develop workplace-relevant training programs. Research shows that it is a valid, cost effective, efficient means of executing functional, occupational, job, and process analysis (Norton, 1997; Halasz, \& Reid, 2003). Norton (1997) stipulated that the DACUM process is based on three premises. First, expert workers can better describe their job than anyone else. Second, any job can be effectively described in terms of the competencies or tasks that successful workers in that occupation perform. Third, the specific knowledge, skills, attitudes, and tools required by workers in order to correctly perform their tasks can also be described. The competency profile generated from the DACUM process "permit[s] a ready appreciation of major areas of responsibility and related major tasks for any role." They are often used to provide information for the development of curricula and learning resources, skills certification, writing of formal job descriptions, and workplace performance evaluations (Cooper et al., 2012, p. 871).

\section{Purpose of the Study}

The purpose of this study was to identify the required competencies for an entry-level position in Forestry and Fire Management. It is the authors' view that identifying competencies associated with jobs in forestry and linking relevant competencies to high and middle school curriculums will expose students to knowledge, skills, and attitudes that are required for students to gain entry level employment in natural resources or go to college to pursue related degrees in natural resources. In addition, working in natural resources that are managed by the Nez Perce Tribe will inevitably expose workers to Nez Perce culture and value system, and understanding and appreciating this culture is important for relationship-building, communication, and the successful execution of daily job functions. Having such cultural competencies, therefore, may be as essential as technical and other competencies. The following questions guided the process:

1. What are the duties, and tasks that constitutes an entry level job in Forestry and Fire Management?

2. What are expert workers' perception of Forestry and Fire Management competencies that should be included in high and middle school curriculums?

\section{Method}

The DACUM process was used. The process involves a focus group panel of 5-12 incumbents who are considered to be expert workers in the particular job. A trained 
facilitator guided the subject matter experts through a process of brainstorming, synergy, consensus building, and validation to develop a competency profile consisting of duties, tasks, general knowledge and skills, attitude, tools, and future trends for that particular job or occupation (Norton, 1997; Halasz, \& Reid, 2003).

Participants. A letter was sent to the management of the Forestry and Fire Management Division of Nez Perce Natural Resources by the project principal investigator explaining the job area that needed to be analyzed for the purpose of the curriculum. The management selected nine workers who they perceived as experts to participate in the workshop. All participants, except two, were members of the Nez Perce Tribe. Their job titles were Fire Prevention and Mitigation Specialist, Fire Management Officer, Forester/Logging Engineer, Engine Operator/Forest Technician, Forestry Technician, Supervisor/ Engine Foreman, Allotment Forester, Inventory and Planning Forester, and Natural Resource Manager.

Procedure. After initial contact was established with the identified expert workers, a letter was sent to each potential participant explaining the DACUM process and why it was necessary. The DACUM workshop was conducted over a period of two days. The facilitator, a recorder, and nine DACUM panel experts were present for the workshop. In addition, four members from Nez Perce Natural Resources management and supervisory staff were present as observers. On the first day, a formal orientation to the DACUM process was provided. The facilitator of the DACUM workshop explained its origin, its philosophy and why it was necessary, and provided examples of DACUM charts from other job areas outside of natural resources. Explanations were given for job duties, job tasks, general knowledge and skills, and worker behaviors. Ground rules for the DACUM workshop were also discussed.

The facilitator then conducted an initial brainstorming of the day-to-day functions of an entry-level fisheries and fire management personnel. These were recorded on a flip chart; when a page was filled it was placed on the wall of the room for all to see. An organizational chart was developed to illustrate where in the organization such a position would be located. The DACUM committee was then asked to study carefully the information collected during the brainstorming process and identify some of the duties that may already be there. After this process was exhausted the committee was asked to identify other duties that were not listed. After a period of discussion and consensus, the recorder wrote each duty on an $8 \times 11$ " card and listed them on the left side of the wall in a vertical column. Each job normally contains 5-12 duties. Tasks statements for each duty were then identified through discussion and consensus. The recorder then wrote each task statement on a $5 \times 8$ " card and placed to the right of the duty statement. Each duty contains between 6-20 tasks.

On the second day, the expert panel worked with the facilitator to sequence the tasks and duties identified on day one by order of importance or logic. General knowledge and skills; attitudes; tools, equipment, supplies and materials; future trends/issues; and important acronyms were then identified. The information obtained from the committee were then entered in a document referred to as a competency profile chart (Norton, 1997). 
Table 2. Future Trends and Attitudes

\begin{tabular}{lll}
\hline Future Trends & General Attitudes & Flexible \\
\hline Global climate changes & Team player & Trustworthy \\
Alternative energy & Conscientious & Motivated \\
Aging workforce & Respectful & Proactive \\
Policy changes & Dependable & Positive \\
Funding sources & Willing to ask questions & Common sense \\
Water rights & Enthusiastic & Organized \\
Changing data technology & Honest & Open-mind \\
Land acquiescing & Accountable & Self-Starter \\
Changes in technology & Detail Oriented & Tactful \\
Drug use policies & Ability to Work Under Pressure & Self-Awareness \\
Increase cost to do business & Optimistic & Multitask \\
\hline
\end{tabular}

To ensure the trustworthiness of the competency profile chart, a draft copy was sent to each committee member about two days after the workshop to check if the duty and task statements accurately reflected what was agreed on by consensus during the workshop. Identified errors and recommended corrections were sent out to the group for agreement. Additionally, the final competency profile was sent to two experts in forestry and fire management, who were not a part of the DACUM committee to verify whether the duties, tasks, general knowledge and skills, attitude, tools, and future trends accurately represented an entry level job in forestry and fire management.

\section{Results}

The results from the committee were recorded on a DACUM chart. Each question of the following questions serves as a guide to present the results obtained from the expert panel.

What are the duties, and tasks that constitute an entry-level job in Forestry and Fire Management? The competency profile identified a total of twelve (12) duties and seventynine (79) tasks for an entry-level Forestry and Fire Management Technician. The duties identified fall under four broad categories:

- Professional and cultural conduct/responsibility,

- Using tools and equipment,

- Development and sustainable practices, and

- Managing fire

Professional and cultural responsibilities include three major duties: (1) appreciating Nimiipuu's culture and values, (2) demonstrating professionalism, and (3) complying with safe work practice. Specific tasks relating to these duties are sharing Nez Perce vision, respecting management, and following fire safety standards respectively. Duties relating to using tools and equipment include: (1) operate basic hand tools and equipment, and (2) perform basic computer skills. Specific tasks generated were performing basic troubleshooting and using GIS/GPS software.

Duties relating to development and sustainable practices include: (1) conducting basic land surveys and mapping, (2) collecting forest inventory data, (3) implementing 
Table 3. Relevant duties and tasks for middle and high school curriculums

Duties and Tasks

\section{A. Appreciate Nimiipuu Culture \& Values}

A-1. Attend Culture Training

A-2. Appreciate Nez Perce heritage

A-3. Share Nez Perce Vision

A-4. Know the content of the Nez Perce Treaties

A-5. Understand the impact of the Nez Perce Treaties

C. Comply with Safe Work Practice

C-1. Evaluate Hazardous Situation

C-2. Perform Basic CPR/ First-Aid

C-3. Comply with Tribal/OSHA Safety Regulations

C-4. Follow Fire Safety Standards

C-5. Operate Motor Vehicles in Safe Manner

E. Perform Basic Computer Skills

E-1. Perform Data Entry

E-2. Use GIS/GPS Software

E-3. Use Microsoft or Relevant Suite

E-4. Manage Electronic Files

E-5. Perform Data Base Development

E-6. Manage Data Base

E-7. Conduct Internet Search

G. Perform Basic Firefighting Duties

G-3. Assess Fire Behavior

G-5. Assess Risks

G-6. Suppress Fire

G-8. Utilize communication System

G-9. Identify Fire Origin

G-10. Protect Fire Origin

G-11. Utilize Incident Command System (ICS)

I. Implement Silvicultural Prescription

I-1. Establish Harvest Boundaries

I-2. Establish Riparian \& Cultural Buffers

I-3. Mark Timber

I-4. Perform Volume Cruise

I-5. Follow BMPs in Sale Layout

\section{B. Demonstrate Professionalism}

B-1. Exhibit good work attitude

B-2. Follow instructions

B-3. Work effectively with others

B-4. Respect management

B-5. Practice good work ethic

B-6. Be timely

B-7. Display personal responsibility

B-8. Communicate with internal \& external stake holder

B-9. Comply with Tribal Policies \& Procedures

D. Operate Basic Hand Tools \& Equipment

D-1. Learn Safe Work Practices

D-2. Maintain Tools in Safe Working Order

D-3. Perform Basic Trouble-Shooting

D-4. Utilize PPE

D-5. Select Appropriate Tools \& Equipment

F. Conduct Basic Land Surveys \& Mapping

F-1. Demonstrate Basic Cartography Skill

F-2. Interpret Public Land Surveying System (PLSS)

F-3. Perform Land Navigation in the Field

F-4. Use Land Navigation Instruments

\section{H. Collect Forest Inventory Data}

H-1. Perform Continuous Forest Inventory (CFI)

H-2. Maintain Permanent Plots

H-3. Perform Regeneration Surveys

$\mathrm{H}-4$. Perform Stand Exams

H-5. Perform Relevant Data Entry

H-8. Utilize UAVs for Remote Sensing

J. Assist with Forest Development Operation

$\mathrm{J}-1$. Collect Cones for Seeding

J-2. Plant Trees

J-3. Protect Seeding

J-4. Monitor Seeding Growth Mortality

J-5. Implement Survival Surveys

silvicultural prescription, and (4) assisting with forest development operation. Specific tasks include interpreting public land surveying system (PLSS), performing regeneration surveys, monitoring seeding growth mortality, and establishing riparian and cultural buffers. Duties relating to managing fires were: (1) performing basic firefighting duties, (2) 
performing hazardous fuel removal, and (3) processing firewood. Specific tasks include assessing fire behavior, pruning trees and transporting firewood.

Future trends that may impact how work is done in forestry and fire management are varied and in the expert workers' opinion, may range from global climate change to the impact of technology. In addition, several general attitudes were identified as enablers for successful job performance. Table 2 describes future trends and general attitudes identified.

What are expert workers' perception of Forestry and Fire Management competencies that should be included in high and middle school curriculums? Ten of the twelve duties and fifty-eight (58) related tasks were identified by the DACUM committee as important for K-12 curriculum. Concepts and procedures relating to these tasks can be integrated in various subjects from middle to high school. Table 3 describes these duties and tasks.

\section{Conclusions and Discussion}

A noteworthy result of the DACUM process was the identification of "Appreciate Nimiipuu's Culture" as one of the twelve duties. There was much deliberation about whether the tasks associated with this duty fit better the category of "Attitude." There was consensus that these tasks are not peripheral or mere enablers for day-to-day functions, but instead they reflect the cultural and spiritual relationship of Nez Perce with the environment and the need to appreciate and respect the wisdom vested in elders about the forest, a connection that learners must understand and appreciate to successfully integrate in the work environment.

Acknowledging the need for these cultural competencies as well as the professional competencies associated with the tasks related to the duty "Demonstrate Professionalism," reflects the strategic thinking of the committee as they contemplate what the current work in forestry and fire management is and what future work should look like. Sanchez (1994), recommends that the validity of tasks related to future jobs can be improved during job analysis by using group techniques to consult with experts, effectively integrating diverse views about future competencies, and examining international trends to discard unlikely views of future work. The DACUM panel, all of whom were expert workers in various capacities (including management), provided the required consultation to validate such tasks. Schneider and Konz (1989) and Brannick and Levine (2002) also recommended using an expert panel when predicting future job changes. Expert panels provide information quicker and cheaper, compared to other methods of conducting job analysis. The expert panel was cognizant of the impact climate change, changes in technology, water rights, and drug use policies will have on how work is done in the industry. The impact of these environmental and social elements on forestry will potentially affect the Nez Perce way of life because of their intricate relationship with the forest.

The contribution of the subject matter experts to the job analysis process demonstrates their appreciation of the importance of Traditional Ecological Knowledge, a form of culturally responsive education, as a framework for the infusion of knowledge, skills, and attitudes into the school curriculum. Berkes, Colding, and Folke (2000) defined Traditional Ecological Knowledge as "a cumulative body of knowledge, practice, and belief, evolving by adaptive processes and handed down through generations by cultural transmission, 
about the relationship of living beings (including humans) with one another and with their environment" (p. 1252). This is an effective framework for the development of curriculum designed to build the STEM identity of Native American students, and such knowledgecentered curriculum has been used successfully to teach Native American students science (Kimmerer, 2012). It brings psychological and intellectual liberation to students because it validates their own cultural knowledge as a context through which STEM can be learned while reinforcing cultural pride (Gay, 2000). According to Howard (2012), it builds bridges of meaningfulness between home and school experiences as well as between academic abstractions and lived sociocultural realities. As they learn STEM through culturally valued knowledge, students will compare and contrast western ways of scientific inquiry with native ways of knowing and practicing science. They are able to develop global awareness by understanding similarities and differences between their realities and those within the global community. Identifying culturally specific duties and their related tasks represents a unique way in which DACUM charts can be used to capture the competency profile for jobs where cultural competencies are integral to the quality of work life.

Performance Assessment. Assessment of proficiency in competencies that are integrated in the middle and high school curriculum can be done through culturally responsive performance assessment. Explaining the importance of such a framework for situated cognition and learning, Lee (1998) stated:

A culturally responsive framework attributes significance to the everyday context of the lives of students who may be African American, Native American, Latino, or live in the Appalachians. Such a framework, for example, looks more closely and carefully at the wisdom of semiliterate elders. It also attributes significant status to the vernacular and non-English language varieties spoken outside of school, the routine household tasks carried out by mothers and children living in poverty and the production of popular art forms like rap music. Practices associated with each of these are viewed as potentially rich intellectual sources and resources for the design and conduct of what Perkins (1992) calls "understanding performances." (p. 274)

Building culturally responsive performance assessment into project-based and inquirybased activities that are designed around competencies associated with tasks identified in the job analysis, and integrated at appropriate levels in middle and high school curriculums, will provide measures for the progressive development (and tracking) of proficiency levels. According to Lee (1998), attributes of culturally responsive performance-based assessments should be linked and integrated directly with curriculum and instruction. The tasks should draw on cultural funds of knowledge from the communities and families of students, as well as the knowledge that students bring from their own youth culture. Project-based or inquiry-based activities should address some community-based authentic need, which may well have political linkages. It should require that students draw on knowledge sources from several disciplines, and they should be working together and with others from outside their schools to find solutions to these issues.

Using experts who are connected to the Nez Perce Tribe to develop the competency profile allowed bias in the process, especially as cultural tasks were identified. What they identified are the competencies they regarded as necessary to get the job done proficiently 
in their work ecology. The competency profile, however, may differ in some respect if the job analysis process was done with a different committee of experts from another region for the same type of job. The competencies captured through the DACUM process reflects what is relevant for this particular job at the Nez Perce Natural Resources. As these competencies are integrated in the school's curriculum, the cultural legacy that must be preserved and transferred to the next generation of forestry workers is of paramount importance to the Nez Perce natural resource experts.

Note: This material is based upon work supported by the National Science Foundation under Grant No. 1513349. Any opinions, findings, and conclusions or recommendations expressed in this material are those of the authors and do not necessarily reflect the views of the National Science Foundation.

\section{References}

Agee, J. K. (1993). Fire ecology of Pacific Northwest forests. Washington, DC: Island Press.

Berkes, F., Colding, J., \& Folke, C. (2000). Rediscovery of traditional ecological knowledge as adaptive management. Ecological Applications, 10, 1251-1262.

Brannick, M. T., \& Levine, E. L. (2002). Job analysis: Methods research and applications for human resource management in the new millennium. Oakland, CA: Sage Publications

Carless, S. A. (2007). Graduate recruitment and selection in Australia. International Journal of Selection and Assessment, 15(2), 153-166.

Chang, I. W., \& Kleiner, B. H. (2002). How to conduct job analysis effectively. Management Research, 25(3), 73-82.

Clifford, J. (1994). Job analysis: Why do it and how should it be done? Public Personnel Management, 23, 321-340.

Cooper, D., Aherne, M., \& Pereira, J. (2012). The competencies required by professional hospice palliative care spiritual care providers. Journal of Palliative Medicine, 13(7), 869-875.

Cucina, J. M., Martin, N. R., Vasilopoulos, N. L., \& Thibodeuax, H. F. (2013). Self-serving bias effects on job analysis ratings. The Journal of Psychology, 146(5), 511-531.

Finch, C. R., \& Crunkilton, J. R. (1999). Curriculum development in vocational and technical education (5th ed.). Boston, MA: Allyn Bacon.

Gatewood, R., \& Field, H. (1994). Human resource selection. Orlando, FL: The Dryden Press.

Gavin, D. G., Hallet, D. J., Hu, F. S., Lertzman, K. P., Prichard, S. J., Brown, K. J., ...Peterson, D. L. (2016). Forest fire and climate change in western North America: Insights from sediment charcoal records. Frontiers in Ecology and the Environment, 5(9), 499-506. https://doi.org/10.1890/06016

Gay, G. (2000). Culturally responsive teaching: Theory, research, \& practice. New York, NY: Teachers College Press.

Ghorpade, J., \& Atchison, T. (1980). The concept of job analysis: A review and some suggestions. Public Personnel Management, 9, 134-144.

Goergen, M., Harding, J., Owen, C., Rey, M., \& Scarlett, L. (2013). The state and future of U.S. forestry and the forest industry. Retrieved from https://www.usendowment.org/wp-content /uploads/2018/10/forest_sector_report_-_final_9.5.13.pdf

Goffin, R. D., Rothstein, M. G., Rieder, M. J., Poole, A., Krajewski, H. T., Powell, D.M., ...Mestdagh, T. (2011). Choosing job-related personality traits: Developing valid personality- 
oriented job analysis. Personality and Individual Differences, 54, 646-651. https://doi.org /1031016/j.paid.1032011.1031006.1031001

Halasz, I. M., \& Reid, T. (2003). Overview of DACUM job analysis process (Report No. 4). Retrieved from NIC Service for Results website: http://static. nicic.gov/Library/010699.pdf

Hamilton, J. (2013). Careers in sustainable forestry. Bureau of Labor Statistics. Retrieved from http://www.bls.gov/green/forestry/sustainable_forestry.htm

Hessburg, P. F., Agee, J. K., \& Franklin, J. F. (2005). Dry forests and wildland fires of the inland Northwest USA: Contrasting the landscape ecology of the pre-settlement and modern eras. Forest Ecology and Management, 211(1-2), 117-139.

Howard, T. C. (2012). Culturally responsive pedagogy. In J. Banks (Ed.), Encyclopedia of Diversity in Education (Vol. 1, pp. 549-552). Thousand Oaks, CA: Sage

Kimmerer, R. W. (2012). Searching for synergy: Integrating traditional and scientific ecological knowledge in environmental science education. Journal of Environmental Studies and Sciences, 2, 317-323.

Latham, G., \& Fry, L. (1988). Measuring and appraising employee performance. In S. Gael (Ed.), The job analysis handbook for business, government, and industry (pp. 902-915). New York, NY: Wiley.

Lee, C. D. (1998). Culturally responsive pedagogy and performance-based assessment. The Journal of Negro Education, 67(3), 268-279.

Morganson, V. J., Major, D. A., \& Bauer, K. N. (2009). Work-life job analysis: Applying a classic tool to address contemporary issues. The Psychologist-Manager Journal, 12, 252274. https://doi.org/ 10.1080/10887150903316305

Morgeson, F. P., \& Campion, M. A. (1997). Social and cognitive sources of potential inaccuracy in job analysis. Journal of Applied Psychology, 82(5), 627-655.

Morgeson, F. P. (2017). Job analysis methods. In S. G. Rogelberg (Eds.), The SAGE encyclopedia of industrial and organizational psychology (2nd ed., pp. 769-771). Thousand Oaks, CA: SAGE Publications.

Nez Perce Tribe Forestry \& Fire Management Division. (2013). Providing economically, socially and environmentally sustainable forest management to the Nez Perce Tribe. Retrieved from https://nezperceforestryandfire.com/

Norton, R. E. (1997). The DACUM handbook. Columbus, Ohio: The Ohio State University Center on Education and Training for Employment.

Northwest Interagency Coordination Center. (2018). Northwest annual fire report 2017. Retrieved from http://gcc.nifc.gov/nwcc/

USDA. (2011). National Report on Sustainable Forests - 2010 (Report No. FS-979). Retrieved from https://www.fs.fed.us/research/sustain/docs/national-reports/2010/2010-sustainability -report.pdf

Sanchez, J. (1994). From documentation to innovation: Reshaping job analysis to meet emerging business needs. Human Resource Management Review, 4(1), 51-74.

Schneider, B., \& Konz. A. (1989). Strategic job analysis. Human Resource Management, 28(1), 51-63. https://doi.org/10.1002/hrm.3930280104

Schuler, R. S., \& Jackson, S. E. (1996). Human resource management: Positioning for the 21st Century. St Paul, MN: West Publishing.

Sherman, A., Bohlander, G., \& Snell, S. (1998). Managing human resources. Cincinnati, OH: South Western College Publishing.

Shetterly, D. R., \& Krishnamoorthy, A. (2008). Job characteristics of officers and agents: Results of a national job analysis. Public Personnel Management, 37(1), 111-131. 
Siddique, C. M. (2004). Job analysis: A strategic human resources management practice. The International Journal of Human Resource Management, 15, 219-244.

Singh, P. (2008). Job analysis for a changing workplace. Human Resource Management Review, 18(2), 87-99.

Stephens, S. L., Collins, B. M., Fettig, C. J., Finney, M. A., Hoffman, C. M., Knapp, E. E., ...Wayman, R. B. (2018). Drought, tree mortality, and wildfire in forests adapted to frequent fire. BioScience, 68(2), 77-88. https://doi.org/10.1093/biosci/bix146

Truxillo, D. M., Paronto, M. E., Collins, M., \& Sulzer, J. (2004). Effect of subject matter expert viewpoint on job analysis results. Public Personnel Management, 33(1), 33-46.

United Nations Food and Agriculture Organization. (2018). Forest management. Retrieved from www.fao.org/forestry/sfm/85084/en/

USDA Forest Service. (2018). Nez Perce-Clearwater national forests. Retrieved from www.fs.usda.gov/main/nezperceclearwater/about-forest

Wallin, D. O., Swanson, F. J., Marks, B., Cissel, J. H., \& Kertis, J. (1996). Comparison of managed and pre-settlement landscape dynamics in forests of the Pacific Northwest, USA. Forest Ecology and Management, 85(1-3), 291-309.

Ward, R., \& Patterson, D. (2012). The impact of wood use on North America forest: Can specifying wood for buildings contribute to forest sustainability? Rethink Wood. Retrieved from www.awc.org/pdf/education/gb/ReThinkMag-GB600A -TheImpactofWoodUseonNorthAmericanForests-1511.pdf

Wooten, W. (1993). Using knowledge, skill and ability (KSA) data to identify career pathing opportunities: An application of job analysis to internal manpower training. Public Personnel Management, 22(4), 551-563.

Zanella, D. J. (1999). Analysis of the industrial technology electrical systems specialization using DACUM. Journal of Industrial Technology, 15(4), 1-6. Retrieved from http://nait.org/jit /Articles/zane0899.pdf

Zilberman, A. (August, 2016). Careers in forestry: Nature’s office suite. Career Outlook, U.S. Bureau of Labor Statistics. Retrieved from https://www.bls.gov/careeroutlook/2016/article /pdf/forestry-careers.pdf 